\title{
Nutritional Constituent of Black Pepper as Medicinal Molecules: A Review
}

\author{
Murlidhar Meghwal and Goswami TK*
}

Agricultural and Food Engineering Department (AgFE), Indian Institute of Technology (IIT) Kharagpur, 721302, India

\begin{abstract}
Based on the usefulness and importance in among the all the spices black pepper is commonly referred as "The King of Spices". It is valued for its flavor, aroma, nutritional and medicinal uses making it an important commodity. By its nature; it is spicy, aromatic and carminative. It is a natural antioxidant. It acts as antiinflammatory, anticancer, antiperiodic and antipyretic. It is rubefacient in nature. It can helps to lower body's cholesterol levels. It contains mainly vitamins $A, C, E, K$, niacin and $\beta$-carotene; and traces of minerals such as iron, calcium, phosphorous. The amino acids contained by black pepper, works for enhancing the bioavailability of nutrients. These acids constituents can be used in antimicrobial, antibacterial applications. All these values of black pepper make it a promising natural health promoting medicine as well as nutrient rich commodity. This critical review elaborates all the above mentioned characteristics in detail, with numerical value and statistical analysis. Based on the analysis and review of last three decades research on black pepper; this review article is mainly focused on usefulness of black pepper as a nutritional and medicinal spice and food commodity.
\end{abstract}

Keywords: Medicinal; Black pepper; Antipyretic; Rubefacient; Anticancer; Diuretic; Antioxidant; Cholesterol lowering; Carminative

\section{Introduction}

Spices are natural food additives which contribute enormously to the taste of our foods. From ancient times they have been used to enliven our foods. Spices possess medicinal as well as nutritional based properties. They have been effectively used as a one of the most important constituents in the medical field worldwide. They have beneficial influence on lipid metabolism efficacy as antidiabetics. They have ability to stimulate digestion and have antioxidant and antiinflammatory (i.e., reduces painful swelling caused by tissue injury) potential [1]. Keeping in mind the potency of spices for medicinal and nutritional uses black pepper was selected and reviewed for its nutritional and medicinal value. The table 1 shows the scientific classification of black pepper in plantae taxonomical classification system.

Black pepper is the dried unripe berries and it gives peppercorn. Peppercorn is dried fruit which has not reached full ripening stage and it is main part which is communicated and used as spice and seasoning. In common language peppercorn is referred to black pepper and it is the most consumable part of pepper plant. The name 'Pepper' comes from the Sanskrit word 'Pippali', meaning "Berry". Table 2 enlists the some of the common names of black pepper in different languages. Black pepper is the almost mature complete berry that is dried and separated from their stalks. It is an angiosperms and it is a climbing type flowering vine. It has a pungent aroma and taste characteristic which makes it desirable by helping to make foods flavorful.

Black pepper is cultivated in different geographical locations of the world. The dried fruit called peppercorn which is processed into powdered form and then used as a spice and seasoning. A fully matured black pepper fruits is approximately five millimeter in diameter but it

\begin{tabular}{|c|c|}
\hline Kingdom & Plantae \\
\hline Division & manoliophyta \\
\hline Class & magnoliopsida \\
\hline Order & piperales \\
\hline Family & piperaceae \\
\hline Genus & Piper \\
\hline Species & Nigram \\
\hline
\end{tabular}

Table 1: Taxonomical Classification of black pepper [20]. turns into four millimeter in diameter after drying. It is almost spherical in shape. Each drupe grows into a single fruit. Black pepper is cultivated mainly in tropical parts of the world. India is known as "The Home of the Black Pepper". Historically black pepper was termed as "The Black Gold" because of its commercial, economical and trade value.

\section{Black pepper reviewed for the following aspects}

Habitat and favorable conditions for black pepper growing: It is perennial shrub indigenous to Malabar and Travancore coast of India. Other than India, it is mainly cultivated in Vietnam, Brazil, Indonesia, Malaysia, Sri Lanka, China, and Thailand. It is cultivated successfully between 200 North and 200 South of equator and 1500 MSL from sea level. It grows well in humid tropical region. It needs high relative humidity with small variation in day and night length. It cannot tolerate excessive heat, cold and dryness. There should be continuous showering of water until the ripening of drupes. It can tolerate the temperature range of $10-40^{\circ} \mathrm{C}$. It is a day neutral plant and direct exposing to sunlight leads to physiological disorder, so $50 \%$ shade is good for boosting its healthy growth [2]

Property of black pepper-physical, chemical, thermal and optical (Table 3)

\section{Chemical composition of black pepper}

Compounds responsible for odor, aroma and pungency in black pepper: The aroma and odor are the most critical and central requirement for any spice and they are combinations of many compounds; in particular for black pepper major compounds responsible for the color, odor and aroma are shown in the Table 4

*Corresponding author: Goswami TK, Professor, Agricultural and Food Engineering Department (AgFE), Indian Institute of Technology (IIT) Kharagpur, 721302, India, Tel: +91 3222 283123(R), 283122(O); Fax: +91-3222-282244 E-mail: tkg@agfe.iitkgp.ernet.in

Received March 30, 2012; Published June 26, 2012

Citation: Meghwal M, Goswami TK (2012) Nutritional Constituent of Black Peppe as Medicinal Molecules: A Review. 1: 129. doi:10.4172/scientificreports.129

Copyright: @ 2012 Meghwal M, et al. This is an open-access article distributed under the terms of the Creative Commons Attribution License, which permits unrestricted use, distribution, and reproduction in any medium, provided the original author and source are credited. 
Citation: Meghwal M, Goswami TK (2012) Nutritional Constituent of Black Pepper as Medicinal Molecules: A Review. 1: 129. doi:10.4172/ scientificreports.129

Page 2 of 7

\begin{tabular}{|c|c|c|c|}
\hline Place & Location specific name & Language & Production \\
\hline \multicolumn{4}{|c|}{ Indian well known names of black pepper in different dialect } \\
\hline Punjab & Kalimirch & Punjabi & No \\
\hline Maharashtra & Ale & Marathi & Yes \\
\hline West Bengal & Kala Mirch, Golmarich & Bengali & No \\
\hline Andhra Pradesh & Miriyalu & Telugu & Yes \\
\hline Tamilnadu & Milagu & Tamil & Yes \\
\hline Gujarat & Kalamari, Kalomirch & Gujarati & Yes \\
\hline Karnataka & Kare menasu & Kannada & Yes \\
\hline Jammu and Kashmir & Marutis & Kashmiri & No \\
\hline Kerala & Kurumulaku, Nallamulaku & Malayalam & Yes \\
\hline Orissa & Gol-maricha & Orriya & No \\
\hline \multirow{2}{*}{ India } & Kalimirch & Hindi & Yes (Major) \\
\hline & Maricha ushana, hopusha & Sanskrit & \\
\hline \multicolumn{4}{|c|}{ Black pepper's name in different languages of the world } \\
\hline England & Black pepper & English & No \\
\hline USA & Black pepper & English & No \\
\hline Bangladesh & Kalimirch, Siahmirch & Urdu & No \\
\hline Nepal & Marich & Nepali & - \\
\hline Germany & Pfeffer & German & - \\
\hline France & Poivre & French & - \\
\hline Portugal & Peper & Dutch & - \\
\hline
\end{tabular}

Table 2: Different names of black pepper in different Indian and international language.

\begin{tabular}{|c|c|c|c|}
\hline Component & Black pepper oil & Black pepper powder & Whole black pepper \\
\hline \multicolumn{4}{|l|}{ Physico-chemical property } \\
\hline Axial dimensions (mm) & - & - & \\
\hline a. Major & - & - & $4.92-5.37$ \\
\hline b. Medium & - & - & $4.59-5.08$ \\
\hline c. Minor & - & - & $4.42-4.89$ \\
\hline Equivalent diameter (mm) & - & - & $4.63-5.10$ \\
\hline Appearance & Colorless to bluish green & Ash like & Black \\
\hline Aroma & Pungent & Pungent & Characteristics of black pepper \\
\hline Viscosity & Low & Flow freely & Rolls freely \\
\hline Specific gravity $\left(25^{\circ} \mathrm{C}\right)$ & $0.860-0.884$ & & \\
\hline Refractive index $\left(25^{\circ} \mathrm{C}\right)$ & $1.487-1.488$ & & \\
\hline True density $\left(\mathrm{kg} \mathrm{m}^{-3}\right)$ & & & 987.71-1012.24 \\
\hline Bulk density $\left(\mathrm{kg} \mathrm{m}^{-3}\right)$ & & & $556.85-542.71$ \\
\hline Porosity $\left({ }^{\circ}\right)$ & & & $43.62-46.38$ \\
\hline Spherecity (\%) & & & $94.22-95.08$ \\
\hline \multicolumn{4}{|l|}{ Thermal properties } \\
\hline Specific heat & 1000 & 1200 & \\
\hline Thermal conductivity $\left(\mathrm{W} \mathrm{m}^{-1}{ }^{\circ} \mathrm{C}^{-1}\right)$ & & 0.16 & $0.1925-0.5986$ \\
\hline \multicolumn{4}{|l|}{ Thermal capacity } \\
\hline Thermal diffusivity $\left(\mathrm{m}^{2} \mathrm{~s}^{-1}\right)$ & & & $12.2 \times 10^{-8}-24 \times 10^{-8}$ \\
\hline \multicolumn{4}{|l|}{ Surface conductance } \\
\hline \multicolumn{4}{|l|}{ Emissivity } \\
\hline \multicolumn{4}{|l|}{ Transmissivity } \\
\hline \multicolumn{4}{|l|}{ Absorptivity } \\
\hline Optical properties & & & \\
\hline
\end{tabular}

Table 3: Major physico-chemical, thermal and optical properties of black pepper. 


\begin{tabular}{|c|c|}
\hline Chemical compound & Type of odor \\
\hline a-terpineol & Floral \\
\hline Acetophenone & Irritant, sharp \\
\hline Hexonal & Green apple \\
\hline Nerol & Fresh,Floral, Herbal \\
\hline Nerolidol & Mild spicy, Rooty \\
\hline $1,8-$ cineol & Camphory \\
\hline Dihydrocarveol & Warm, Woody \\
\hline Citral & Citrussy \\
\hline$a-$-pinene & Terperic, Oxidised \\
\hline Piperolnol & Sweet, Floral \\
\hline
\end{tabular}

Table 4: Major chemical compounds responsible for the aroma, pungency and medicinal property of the black pepper.

which are found out from GCMS analysis [3]. It contains lignans, alkaloids, flavonoids, aromatic compounds and amides [4]. It also contains essential oil up to $3.5 \%$ and this oil constitutes sabinene, pinene, phellandrene, linalool and limonene. It also has piperine which is a weak basic substance. Chavicine is an isomer of piperine [5]. Piperine and Chavicine are not responsible for the aroma of the black pepper but piperine imparts pungency to the black pepper [6,7].

Vitamins content in black pepper: Choline, Folic acid, Niacin, Pyridoxine, Riboflavin, Thiamin, Vitamin A, and Vitamin C

Vitamins A, Vitamin E, Vitamin $\mathrm{K}$ are the major vitamins found in the black pepper.

Minerals content of black pepper: Calcium, Copper, Iron, Magnesium, Manganese, Phosphorus, Zinc are the main minerals found in the black pepper (Table 5)

Pharmacological, toxicological and clinical applications and general uses of black pepper: Pepper is known as a health improving natural medicine which increases digestive power, improves appetite, cures cold, cough, diseases of the throat, intermittent fever, colic, dysentery, worms and piles [6]. It stimulates circulatory system. It possesses a broad spectrum antimicrobial activity. Analgesic (alleviate pain), antipyretic (reduces fever) and antiinflammatory actions are described, with piperine having been shown to be one of the active compounds in such cases. A protective impact of black pepper on key liver enzymes has been noted (Figure 1). As evaluated based on the Ames test, in mutagenic and carcinogenic properties of pepper gave favorable results. The antioxidant capacity of pepper phenolic amides was shown to be superior to the synthetic moieties BHT (Butylated hydroxytoluene, antioxidant synthetic food additive) and BHA (Butylated hydroxyanisole, synthetic antioxidant consisting of a mixture of two isomeric organic compounds).

Bioavailability enhancement: Black pepper and its volatile oil are used in food and food items to aid a) Digestion b) Relieve gas c) Treat food poisoning d) Stomach chills e) Cholera f) Dysentery g) Vomiting caused by hypothermia. Unripe, fresh green berries are used in sauces and to flavor various savory dishes [8]. Ayurvedic medicine uses pepper mixed with ghee (buttery type of compound) to treat external problem, nasal congestion, sinusitis, skin eruptions, epilepsy. Piperine increases the bioavailability of valuable phyto-chemicals present in food items and can boost the activity of biochemically active compounds contained in it. It promotes the rapid absorption of certain chemicals from the gastrointestinal tract, protecting them from being broken down by chemicals in the intestinal lumen and by enzymes that occur in the cells lining of intestines [9]. Once the compound has entered the blood stream, piperine provides protection against oxidative damage with the help of liver enzymes [9]. In this way black pepper enables us to reap optimum benefits from the medicinal phytochemicals found in other dietary spices. Black pepper's bioavailability enhancing properties makes it as one of the most important Spices [9]. It should add to recipes and meals as often as possible because it boosts the medicinal value of many spices and other foods. Piperine extracted from pepper is a bioavailability enhancer that allows substances to remain in cells for longer periods of time. The researchers concluded that piperine enhances the serum concentration, extent of absorption and bioavailability of curcumin in both rats and humans with no adverse effects. This means that a low dose of curcumin could have a greater effect in terms of health benefits when combined with piperine than a large dose of curcumin or turmeric would.

Pungent test and aroma: Black pepper is pungent, aromatic and warming in nature. Its pungent nature is due to the presence of alkaloid piperine.

Carminative: Pepper has a high degree of the stimulating and carminative properties, causing a reflex flow of saliva, with increased secretion of gastric juice and improved appetite [10]. Gastro-intestinal movements are augmented, with consequent eructation of gas and relief of colic. In sufficient doses, the peppers dilate the superficial vessels of the skin, causing a feeling of warmth, followed by diaphoresis and some reduction of temperature [10]. On account of these properties they are much employed as condiments [10], especially in hot countries. The pathological condition in which such painful masses occur, also called piles and black pepper is used as remedy for hemorrhoids. An oleoresin of pepper is prepared by extraction with acetone and separation from piperine.

Anti-cancer: By increasing the bioavailability of other antitumor spices, black pepper dramatically increases their potency and effectiveness against cancer [9]. Black pepper counteracts cancer development directly. Its principal phytochemical, piperine, inhibits some of the pro-inflammatory cytokines that are produced by tumor cells [9]. In doing so it interferes with the signaling mechanisms between cancer cells, thereby reducing the chances of tumor progression. Collectively, these properties make black pepper one of the most important spices for preventing cancer. Pepper prevents chemical carcinogenesis by stimulating the xenobiotic biotransformation enzymes [6]. The antioxidant properties of piperine and associated unsaturated amides play a preventive role in carcinogenesis. Dietary intake of natural antioxidants could be an important aspect of the body's defense mechanism against the degradative changes caused by mutagens. The essential oil constituents inhibits DNA adduct formation by xenobiotics. This observation shows the anti-carcinogenic potential of pepper [6]. Hexane, water and alcohol extracts of pepper were tested for mutagenic capacity on

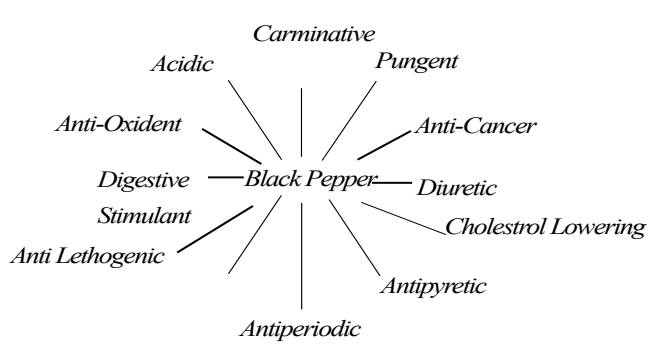

Figure 1: Some of the principle medicinal traits of black pepper. 
Citation: Meghwal M, Goswami TK (2012) Nutritional Constituent of Black Pepper as Medicinal Molecules: A Review. 1: 129. doi:10.4172/ scientificreports.129

Page 4 of 7

\begin{tabular}{|c|c|c|c|c|c|c|c|c|c|c|c|c|c|c|c|c|c|c|}
\hline \multirow[t]{2}{*}{ Variety } & \multirow[t]{2}{*}{ Pedigree } & \multirow{2}{*}{$\begin{array}{l}\text { Origin and } \\
\text { production } \\
\text { centre }\end{array}$} & \multirow{2}{*}{$\begin{array}{l}\text { Yield } \\
\text { (dry) } \\
\text { kg/ha) }\end{array}$} & \multicolumn{2}{|c|}{ Piperine (\%) } & \multirow{2}{*}{$\begin{array}{l}\text { Oleoresin } \\
(\%)\end{array}$} & \multicolumn{2}{|c|}{$\begin{array}{l}\text { Essential oil } \\
(\mathrm{mg} / 100 \mathrm{~g})\end{array}$} & \multicolumn{2}{|c|}{$\begin{array}{l}\text { Phenols } \\
\text { (mg\%) }\end{array}$} & \multicolumn{2}{|c|}{$\begin{array}{l}\text { Free amino } \\
\text { acids } \\
(\mathrm{mg} \%)\end{array}$} & \multicolumn{2}{|c|}{ Starch (mg\%) } & \multicolumn{2}{|c|}{$\begin{array}{l}\text { Total } \\
\text { carbohydrate } \\
(\mathrm{mg} \%)\end{array}$} & \multicolumn{2}{|c|}{ Protein $(\mathrm{mg} \%)$} \\
\hline & & & & Leaves & Berry & & Leaves & Berry & Leaves & Berry & Leaves & Berry & Leaves & Berry & Leaves & Berry & Leaves & Berry \\
\hline $\begin{array}{l}\text { Panniyur } \\
1(\mathrm{KAU})\end{array}$ & $\begin{array}{l}\text { Hybrid between } \\
\text { Uthirankotta } \\
\text { xCheriyakaniakadan }\end{array}$ & Kerala, India & 1242 & 0.0004 & 2.8 & 8.5 & 0.12 & 2.4 & 0.8 & 0.5 & 0.4 & 0.4 & 1.5 & 34.1 & 2.6 & 38.6 & 1.25 & 5.2 \\
\hline $\begin{array}{l}\text { Panniyur } \\
2(\mathrm{KAU})\end{array}$ & $\begin{array}{l}\text { Selection (Cul. 141) } \\
\text { from cv. } \\
\text { Balancotta }\end{array}$ & Kerala, India & 2570 & 0.002 & 3.1 & 8.5 & 0.1 & 3.2 & 0.7 & 0.5 & 0.5 & 0.4 & 1.4 & 36.0 & 3.0 & 40.2 & 1.6 & 4.3 \\
\hline $\begin{array}{l}\text { Panniyur } \\
\text { 3(KAU) }\end{array}$ & $\begin{array}{l}\text { Hybrid (Cul. 331) } \\
\text { Uthirankotta x } \\
\text { Cheriyakaniakadan }\end{array}$ & Kerala, India & 1953 & 0.002 & 1.8 & 6.8 & 0.1 & 3.2 & 0.7 & 0.4 & 0.9 & 0.3 & 0.5 & 32.1 & 1.6 & 37.3 & 1.8 & 2.1 \\
\hline $\begin{array}{l}\text { Panniyur } \\
4(\mathrm{KAU})\end{array}$ & $\begin{array}{l}\text { Selection from } \\
\text { Kuthiravally Type }\end{array}$ & Kerala, India & 1277 & 0.001 & 3.8 & 11 & 0.2 & 5.0 & 0.5 & 0.5 & 0.9 & 0.5 & 1.8 & 43.2 & 3.9 & 49.3 & 1.0 & 2.3 \\
\hline $\begin{array}{l}\text { Panniyur } \\
5(\mathrm{KAU})\end{array}$ & $\begin{array}{l}\text { Open pollinated } \\
\text { progeny } \\
\text { selection from } \\
\text { Perumkodi }\end{array}$ & Kerala, India & 1098 & 0.0003 & 3.6 & 9.5 & 0.2 & 2.8 & 0.6 & 0.6 & 0.6 & 0.3 & 1.7 & 42.0 & 3.5 & 46.2 & 1.2 & 3.5 \\
\hline $\begin{array}{l}\text { Panniyur } \\
6(\mathrm{KAU})\end{array}$ & $\begin{array}{l}\text { Clonal selection from } \\
\text { Karimunda }\end{array}$ & Kerala, India & 2127 & 0.00006 & 3.6 & 8.6 & 0.2 & 2.6 & 0.5 & 0.6 & 0.3 & 0.4 & 0.8 & 41.1 & 3.2 & 44.2 & 1.9 & 4.6 \\
\hline $\begin{array}{l}\text { Panniyur } \\
7(\mathrm{KAU})\end{array}$ & $\begin{array}{l}\text { Open pollinated } \\
\text { progeny selection } \\
\text { from Kuthiravally }\end{array}$ & Kerala, India & 1410 & 0.0003 & 3.5 & 8.7 & 0.2 & 2.6 & 0.6 & 0.7 & 0.5 & 0.3 & 1.1 & 43.2 & 2.9 & 51.2 & 1.5 & 2.1 \\
\hline $\begin{array}{l}\text { Subhakara } \\
\text { (IISR) }\end{array}$ & $\begin{array}{l}\text { Selection from } \\
\text { Karimunda (KS-27) }\end{array}$ & India & 2352 & 0.0005 & 4.0 & 13.9 & 0.2 & 6.0 & 0.3 & 0.6 & 0.3 & 0.3 & 1.4 & 42.7 & 4.8 & 46.4 & 2.3 & 4.3 \\
\hline $\begin{array}{l}\text { Sreekara } \\
\text { (IISR) }\end{array}$ & $\begin{array}{l}\text { Selection from } \\
\text { Karimunda (KS-14) }\end{array}$ & India & 2677 & -- & 4.2 & 9.6 & 0.2 & 4.0 & 0.7 & 0.6 & 0.3 & 0.3 & 1.8 & 42.2 & 2.8 & 45.1 & 2.8 & 3.6 \\
\hline $\begin{array}{l}\text { Panchami } \\
\text { (IISR) }\end{array}$ & $\begin{array}{l}\text { Selection from } \\
\text { Aimpiriyan (Coll. 856) }\end{array}$ & India & 2828 & 0.001 & 4.1 & 10.5 & 0.2 & 2.8 & 0.5 & 0.5 & 0.3 & 0.4 & 1.2 & 36.0 & 3.2 & 39.2 & 2.4 & 3.7 \\
\hline $\begin{array}{l}\text { IISR } \\
\text { Thevam }\end{array}$ & $\begin{array}{l}\text { Clonal selection of } \\
\text { Thevamundi }\end{array}$ & India & 2481 & 0.0008 & 1.6 & 8.2 & 0.3 & 2.8 & 0.6 & 0.5 & 0.4 & 0.3 & 1.5 & 35.1 & 2.6 & 38.6 & 1.2 & 3.3 \\
\hline $\begin{array}{l}\text { IISR } \\
\text { Girimunda }\end{array}$ & $\begin{array}{l}\text { Hybrid between } \\
\text { Narayakodi } x \\
\text { Neelamundi }\end{array}$ & India & 2880 & 0.003 & 2.2 & 8.9 & 0.2 & 3.0 & 0.3 & 0.3 & 0.3 & 0.4 & 0.7 & 38.7 & 2.5 & 41 & 1.8 & 3.0 \\
\hline $\begin{array}{l}\text { Malabar } \\
\text { excel }\end{array}$ & $\begin{array}{l}\text { Hybrid between } \\
\text { Cholamundi x } \\
\text { Panniyur-1 }\end{array}$ & India & 1440 & $\ldots$ & 3.0 & 12 & 0.1 & 3.2 & 0.4 & 0.4 & 0.3 & 0.6 & 2.1 & 36.4 & 3.1 & 39.6 & 2.0 & 2.7 \\
\hline Kottaram & & & & trace & 3.8 & 9.0 & 0.2 & 3.2 & 0.4 & 0.3 & 0.5 & 0.3 & 0.7 & 40.2 & 2.4 & 45.1 & 1.5 & 2.1 \\
\hline TMB IV & & & & & & 7.0 & 0.1 & 1.6 & 0.7 & 0.5 & 0.2 & 0.5 & 0.8 & 38.2 & 4.5 & 46 & 1.5 & 3.5 \\
\hline Neelamundi & & & & 0.008 & 2.0 & 10.2 & 0.3 & 3.5 & 0.9 & 0.4 & 0.7 & 0.8 & 0.6 & 37.1 & 2.1 & 40.2 & 1.9 & 4.1 \\
\hline Karimunda & & & & 0.002 & 3.7 & 9.3 & 0.2 & 4.0 & 0.5 & 0.5 & 0.3 & 0.6 & 0.8 & 35.3 & 2.6 & 40.1 & 1.3 & 5.1 \\
\hline Vally & & & & 0.008 & 2.0 & 5.9 & 0.2 & 2.6 & 0.8 & 0.5 & 0.5 & 0.6 & 1.7 & 38 & 3.7 & 40.6 & 1.3 & 5.2 \\
\hline Vattamunda & & & & 0.0003 & 3.1 & 8.6 & 0.2 & 2.5 & 1.2 & 0.5 & 0.7 & 0.4 & 1 & 40.1 & 3.1 & 44 & 1.1 & 6.0 \\
\hline Aimpirian & & & & 0.0006 & 3.3 & 6.9 & 0.2 & 2.4 & 0.9 & 0.5 & 0.7 & 0.4 & 0.9 & 39.2 & 3.3 & 45.8 & 1.2 & 3.6 \\
\hline Angamali & & & & 0.0003 & 3.0 & 7.3 & 0.3 & 2.8 & 0.6 & 0.5 & 0.9 & 0.5 & 0.6 & 33.5 & 3.6 & 39.4 & 1.8 & 4.3 \\
\hline Kalluvally & & & & 0.002 & 2.8 & 8.1 & 0.2 & 3.3 & 1.1 & 0.5 & 0.5 & 0.5 & 1.1 & 42.8 & 3.5 & 46.8 & 2.0 & 3.8 \\
\hline Kottanadan & & & & trace & 3.8 & 9.0 & 0.3 & 5.5 & 0.7 & 0.4 & 0.3 & 0.4 & 1.0 & 39.1 & 1.9 & 48.5 & 2.0 & 5.2 \\
\hline HP-785 & & & & 0.001 & 2.4 & 7.2 & 0.3 & 3.2 & 1.2 & 0.4 & 0.3 & 0.5 & 0.7 & 33.5 & 3 & 39.6 & 1.4 & 3.7 \\
\hline HP-1117 & & & & 0.0001 & 2.6 & 7.5 & 0.3 & 2.0 & 1.2 & 0.5 & 0.4 & 0.5 & 0.7 & 37.3 & 4.6 & 42.2 & 2.7 & 3.5 \\
\hline HP-846 & & & & 0.0004 & 2.6 & 7.6 & 0.1 & 2.4 & 1.5 & 0.6 & 0.4 & 0.5 & 2 & 35 & 4.6 & 40.1 & 2.8 & 3.1 \\
\hline
\end{tabular}

Table 5: Major cultivars of black pepper and their constitutes analysis [21].

Salmonella typhimurium strains TA 98 and TA 100 by Ames assay and the results indicated the non-mutagenic effects of the extracts $[6,9]$. The volatile oil and its constituents suppress the formation of DNA adducts with aflatoxin B1. The pepper terpenoid d-limonene was found to reduce the carcinogenic activity of methycholanthrene, a potent carcinogenic compound. Two minor constituents of pepper, safrole and tannic acid, are attributed with minor carcinogenic activity. In a tissue culture study using V-79 lung fibroblast cell lines, reported that piperine treated cell lines showed increased DNA damage compared to untreated ones. Piperine treatment lowered the activities of the enzymes glutathione-s-transferase and uridine diphosphate glucuronyl transferase indicating the cytotoxic potential. The in vivo formation of n-nitroso compounds from naturally occurring amines and amides contribute to the carcinogenic potential of certain foods and food additives. Piperine and other phenolic amides present in pepper are also known for their conversion to n-nitroso compounds in acidic conditions and hence treated as carcinogenic But it can be inferred that the presence of conjugated unsaturated system in the phenolic amide prevents the oxidation of the amide nitrogen to $n$-nitroso compounds to a large extent [6]. Moreover, the essential oil constituents of pepper also contribute to its anti-carcinogenic potential preventing DNA damage. Investigations reveal both carcinogenic and anti-carcinogenic nature. However, pepper as such exhibited anti-mutagenic and anticarcinogenic effects.

Natural antioxidant content and its activity in black pepper: Antioxidant compounds in food items play important roles as healthprotecting factors. Antioxidants are widely used as additives in fats, oils and in food processing to prevent or delay spoilage of foods. Black pepper is a centre of attraction as sources of effective antioxidants [6]. It contains several powerful antioxidants and is thus one of the most important spices for preventing and curtailing oxidative stress [9]. In addition to their direct antioxidant properties, several of these compounds work indirectly by enhancing the action of other 
antioxidants. Saturated fats in the food are one of the main causes of oxidative stress and black pepper minimizes it [9]. The high levels of cholesterol and triglycerides associated with oxidative stress inhibit the efficacy of important antioxidants like glutathione, superoxide dismutase, catalase, glutathione peroxidase, vitamin $\mathrm{C}$ and vitamin $\mathrm{E}$. Black pepper actually maintains and enhances the levels and efficacy of important antioxidant compounds. Oxidation is a leading cause for quality deterioration during processing and storage of muscle foods. When stored at refrigerated temperatures, lipids in meat oxidize and unsaturated fatty acids form hydroperoxides that are subsequently decomposed to secondary products, including malonaldehyde (MDA) and other carbonyl compounds that cause off-flavours [11]. The best way to overcome this problem is to use natural antioxidant which is obtained from plant origin because synthetic antioxidant has many side effects. As black pepper has antioxidant property. It may be one of the best natural anti-oxidant to be used to prevent oxidation and off flavor in meat and its products. Suhaj [12] study showed the some of the major anti-oxidant of the black pepper (Table 6).

The free radical scavenging activity of the different fractions of pet ether extract of piper nigrem was observed in an increased manner in a concentration dependent manner [13].

Black pepper as an anti-inflammatory drug: Inflammation is complex biological response of vascular tissues to harmful stimuli, such as pathogens, damaged cells, or irritants and anit-inflammatory means something which reduces the human body inflammation and black pepper is one of such substance. Anti-inflammatory drugs make up about half of analgesics, remedying pain by reducing inflammation as opposed to opioids which affect the central nervous system. Antiinflammatory drugs used for treating chronic inflammatory diseases such as rheumatoid arthritis are typically prescribed long term to properly control the disordered immune system. It is found that piperine significantly inhibited the production of two important proinflammatory mediators, IL6 and PGE, in IL1 $\beta$-stimulated human FLS. The inhibition of $\mathrm{PGE}_{2}$ production is important due to its central role in triggering pain. In addition, MMP1 and MMP13 collagenases play dominant roles in RA and osteoarthritis because they are the rate-limiting components of the collagen degradation process. The significant inhibition of MMP13 expression is particularly important because it degrades a wide range of collagenous and non-collagenous extracellular matrix macromolecules and is remarkably active against

\begin{tabular}{|c|c|}
\hline Ascorbic-acid & $0-10 \mathrm{ppm}$ \\
\hline Beta-carotene & $0.114-0.128 \mathrm{ppm}$ \\
\hline Camphene & \\
\hline Carvacrol & \\
\hline Eugenol & \\
\hline Gammaterpinene & $400-447 \mathrm{ppm}$ \\
\hline Lauric-acid & \\
\hline Linalyl-acetate & \\
\hline methyl-eugenol & \\
\hline myrcene & $700-782 \mathrm{ppm}$ \\
\hline myristic-acid & \\
\hline myristicin & $12,200-13,633 \mathrm{ppm}$ \\
\hline palmitic-acid & $17,000-90,000 \mathrm{ppm}$ \\
\hline piperine & \\
\hline terpinen-4-ol & \\
\hline ubiquinone & \\
\hline
\end{tabular}

Table 6: Antioxidant active chemicals isolated from black pepper pepper [12] collagen type II, the predominant collagen in cartilage [6,12]. Piperine inhibits the expression of MMP13 in IL1 $\beta$-stimulated FLSs. [6]. Piperine showed a significant inhibition of increase in oedema volume in a carragenin induced test. Piperine acted significantly on early acute changes in inflammatory process [14].

Cholesterol lowering: Pepper doesn't have cholesterol. It enhances digestion process by helping faster break down of larger fat molecules into easily digestible simple molecules and prevents the accumulation of fat in body.

Immune enhancer: Black pepper exhibits immunomodulatory effect on human body. It is able of boost and supports the number and the efficiency of white cells and assists the body to raise a powerful defense against invading microbes and cancer cells. Lianzhong et al. [15] found that the analysis of component PN-IIa showed a different monosaccharide composition, which contained a significant proportion of galactose, arabinose, galacturonic acid and rhamnose; and PN-IIa did react with $\beta$-glucosyl Yariv reagent, which indicated that $\mathrm{PN}$ IIa might be an arabinogalactan; and purified anti-complementary polysaccharides from Piper nigrum is suggested as a supplement for immune enhancement.

Anti-pyretic: Ayurvedic, Yunani, Siddha and folklore medicines in India used pepper and pepper containing preparations for the treatment of intermittent fever, neuritis, cold, pains and diseases of throat are practiced in Pepper is also used as an anti-periodic in malarial fever and therefore it is claimed having analgesic and antipyretic properties. Analgesic and antipyretic actions of piperine have been experimented on rabbit and mice and found strong antipyretic effect on typhoid vaccinated rabbits at a dose of $30 \mathrm{mg} / \mathrm{kg}$ body weight. Singh et al. [14] reported that piperine gave a strong activity with an ED50 of $3.7 \mathrm{mg} / \mathrm{kg}$ on writhing method and $104.7 \mathrm{mg} / \mathrm{kg}$ on tail clip method.

Anti-periodic: It helps in get rid of frequent fever such as malaria. It acts as stimulant.

Rubefacient: If we apply powder of pepper on our skin it get stimulated and become red. The berries are used externally as rubefacient in baldness and skin diseases. The berries are decocted and the solution is used as a mouthwash for toothache [16].

Black pepper as antibacterial and antimicrobial agent: Black pepper possesses antibacterial activity. The finding of antimicrobial activity in water extracts may be useful for the food industry as water soluble compounds penetrate easily into the food matrix than solvent extracted oleoresins or essential oils. These extracts therefore have potential to extend the shelf-life or improve the safety of foods items (Table 7).

The decoction when taken internally is used for dyspepsia, cough, and intermittent fever treatment. The berries can be prepared in the form of liniment for chronic rheumatism. A water infusion of the corns is used as a gargle in various infections in the throat. The berries are used in topping vomiting in cases of cholera. The juice of the leaves is boiled in oil and the mixture is applied externally against scabies. The roots are boiled in water and the solution is used as tonic, stimulant, cordial, and anthelmintic [17].

Black pepper improves digestion and promotes intestinal health: It has been found that piperine can increase absorption of selenium, vitamin B, beta-carotene and curcumin as well as other nutrients. It can improve digestion and stimulate the secretion from 
Citation: Meghwal M, Goswami TK (2012) Nutritional Constituent of Black Pepper as Medicinal Molecules: A Review. 1: 129. doi:10.4172/ scientificreports.129

Page 6 of 7

\begin{tabular}{|c|c|c|c|}
\hline Application/ Utility & Responsible components & Problem addressed & References \\
\hline Analgesic & piperine & & [22] \\
\hline Antipyretic & Piperine & & [1] [22] \\
\hline \multicolumn{4}{|l|}{ Rubefacient } \\
\hline $\begin{array}{l}\text { Inhibits lipopolysaccharide induced inflammatory } \\
\text { responses }\end{array}$ & Piperine & & [23] \\
\hline Intermittent fever, colic, dysentery, worms and piles & Piperine & & [22] \\
\hline Cures cold cough, dyspnoea, diseases of the throat & piperine & Improves breathing, reduce cough & [22] \\
\hline Improves appetite & Piperine & & [22] \\
\hline Increases digestive power & Piperine & & [22] \\
\hline Antimicrobial activity & Piperine & & [22] \\
\hline A protective impact upon key liver enzymes & & Proper liver functioning & [22] \\
\hline Antioxidant & $\begin{array}{l}\text { Pepper phenolic amides, phenolic acids } \\
\text { and flavonoids }\end{array}$ & $\begin{array}{l}\text { Prevent DNA damage, cells, } \\
\text { control oxidative stress }\end{array}$ & [22] [4] \\
\hline Mutagenic and carcinogenic properties & & Cancer & [22] \\
\hline Spice, Culinary applications & Fruits, peppercorn & Improves food quality & {$[4]$} \\
\hline Preservatives & Fruits, leaves & Prevent food spoilage & [4] \\
\hline Cosmetic industry & Peppercorn & Improves beauty & [4] \\
\hline Insecticides & Peppercorn & Natural insecticide & [4] \\
\hline
\end{tabular}

Table 7: Pharmacological, toxicological and clinical applications and general uses.

the taste buds and taste bud stimulation is a feedback loop for digestion process. It sends impulses to the stomach to increase digestive juices secretion such as hydrochloric acid. These juices break down the protein in the stomach, improving ability for further digestion in the duodenum. Bile acids are important for fat digestion and absorption and pepper constituents stimulate bile acid production by the liver and its secretion into bile [1]. Lack of hydrochloric acid secretion leads to poor digestion, heartburn, or symptoms of indigestion in the human body. When the body's production of hydrochloric acid is insufficient, food may retains in the stomach for an extended period of time, leading to heartburn or indigestion, or it may pass into the intestines, where it can be used as a food source for unfriendly gut bacteria, whose activities produce gas, irritation, or diarrhea or constipation [18]. In addition, it has diaphoretic (promotes sweating) and diuretic (promotes urination) properties [11]. this wonderful seasoning promotes the health of the digestive tract and not only does help to derive the most benefit from food, the outer layer of the peppercorn stimulates the breakdown of fat cells, keeping human slim while giving energy to work [18]

Processing problem and preservation of the flavor content of black pepper: Black pepper mainly available in two different forms: a) Whole black pepper b) Fine powder of black pepper. People prefer to buy the whole peppers and grind to powder just before adding it to the recipe [19]. This is done to ensure the best flavor. The ideal way of storing peppers is by keeping them in a tightly sealed container in a cool, dark and dry room. This way, whole peppercorns can be kept for indefinite period, while the fresh ones can be kept for a maximum of three months [19]. It can also be stored by freezing it, but this will cause a substantial decrease in the flavour. While grinding care should be taken because its fine dust may cause nose burning, sneezing and coughing. Cryogenic grinding is a novel approach to grind the black pepper at low temperature so that its favor, aroma, odor and natural taste can be retained.

Precautions to be taken before use of black pepper seed, powder and its volatile oil: Excessive topical use of black pepper essential oil may over stimulate the kidneys [8]. The pregnant women should not much use it because its pungency can cause burning session on the body of infant and its consumption should be avoided during pregnancy. Black pepper powder's contact on the human body can cause redness on skin. Piperine have no significant influence on blood and liver cholesterol or triglyceride in experimental animals fed at varying levels corresponding to 1-10 times human dietary intake [1]. Studies with pepper extracts showed an increased incidence of tumour in mice and, an elevated level of DNA damage caused by piperine in cell culture investigation [6].

\section{Conclusion}

Present day consumers are health conscience and they prefer natural food items which free of synthetic additives, colorant, artificial adhesive; pepper is one of such commodity which can provide natural nutritional and medicinal benefit. It has analgesic, antipyretic, antiinflammatory, antimicrobial and antineoplastic properties and; they were studies in this review. There is a scope for developing pepper based insecticides and insect repellents which are nontoxic to human beings. Piperine is the major alkaloidal constituent of pepper. Systematic pharmacological studies on piperine have revealed its analgesic, antipyretic, anti-inflammatory and central nervous system depressant activities. Black pepper improves digestion by stimulating the taste buds in such a way that an impulse is sent to the stomach to increase hydrochloric acid secretion. The essential oil constituents are mainly responsible for the antimicrobial actions. Very promising results could be obtained in insecticidal and insect repellent properties also. These surmised all information on medicinal and nutritional value assessment of black pepper will find its utility in academic field, scientific research and real world industrial application.

\section{References}

1. Srinivasan K (2005) Spices as influencers of body metabolism: an overview of three decades of research. Food Res Int 38: 77-86.

2. http://spices.indianetzone.com/1/black_pepper_farming.html

3. Murthy CT, Bhattacharya S (2008) Cryogenic grinding of black pepper. J Food Eng 85:18-28.

4. Agbor GA, Vinson JA, Oben JE, Ngogang JY (2006) Comparative analysis of the in vitro antioxidant activity of white and black pepper. Nutrition Research 26: 659-663.

5. Ahluwalia VK, Raghav S (1997) Comprihensive experimental chemistry. New Age International Publishers, New Delhi.

6. Vijayan KK, Thampuran RVA (2000) Pharmacology, toxicology and clinical applications of black pepper. Harwood Academic Publishers. 
Citation: Meghwal M, Goswami TK (2012) Nutritional Constituent of Black Pepper as Medicinal Molecules: A Review. 1: 129. doi:10.4172/ scientificreports.129

7. Jain K (2006) Holistic health healing and astrosciences. An international source book, B Jain Publishers, New Delhi.

8. http://www.ageless.co.za/herb-black-pepper.htm

9. http://health.learninginfo.org/black-pepper.htm

10. http://www.henriettesherbal.com/eclectic/bpc1911/piper-nigr.html

11. Kaefer CM, Milner JA (2008) The role of herbs and spices in cancer prevention. J Nutr Biochem 19: 347-361.

12. Suhaj M (2006) Spice antioxidants isolation and their antiradical activity: a review. J Food Compost Anal 19: 531-537.

13. Shoba G, Joy D, Joseph T, Majeed M, Rajendran R, et al. (1998) Influence of piperine on the pharmacokinetics of curcumin in animals and human volunteers. Planta Med 64: 353-360.

14. Singh R, Singh N, Saini BS, Rao HS (2008) In vitro antioxidant activity of pe ether extract of black pepper. Indian J Pharmacol 40: 147-151.

15. Lianzhong D, Zhu-Yan, Shiyue D, Li-Yixu, Songmei Z (1998) A study on chemical composition of spices irradiated by electron beam. Radiat Phys Chem 52: $49-52$
16. http://healthmad.com/alternative/blackpepperanti-throat-infectiondyspepsiaand-other-medicinal-uses/

17. http://healthmad.com/alternative/blackpepperanti-throat-infectiondyspepsiaand-other-medicinal-uses/

18. http://www.whfoods.com/genpage.php?tname=foodspice \&dbid=74

19. http://lifestyle.iloveindia.com/lounge/nutritional-value-of-black-pepper-5961. $\mathrm{html}$

20. Ayushveda. Botanical classification.

21. Zachariah TJ, Safeer AL, Jayarajan K, Leela NK, Vipin TM, et al. (2010) Correlation of metabolites in the leaf and berries of selected black pepper varieties. Sci Hortic 123: 418-422.

22. Deans SG (2001) Black Pepper, Piper nigrum. Medicinal and Aromatic PlantsIndustrial Profiles, Book reviews, Phytochemistry 58: 827-829

23. Bae GS, Kim MS, Jeong J, Lee HY, Park KC, et al. (2011) Piperine ameliorates the severity of cerulein-induced acute pancreatitis by inhibiting the activation of mitogen activated protein kinases. Biochem Biophys Res Commun 410: 382388. 